УДК $619: 616.411-02: 636.7$

(C) 2015

\author{
Локес П. І., доктор ветеринарних наук, \\ Кравченко С. О., кандидат ветеринарних наук
}

Полтавська державна аграрна академія

\title{
ХАРАКТЕРИСТИКА ОКРЕМИХ ЧИННИКІВ СПЛЕНОМЕГАЛІЇ У СВІЙСЬКИХ СОБАК
}

\section{Рецензент - доктор ветеринарних наук, професор Б. П. Киричко}

У роботі представлені результати наукового дослідження щодо вивчення етіологічних чинників, клінічних проявів, показників лабораторних досліджень та змін ультрасонографічних ознак за спленомегаліі y собак. Встановлено, шьо етіологічними чинниками спленомегалії є патології, щио супроводжуються порушенням кровообігу, гемопоезу та пігментного обміну. Клінічними симптомами спленомегалії $є$ збільшення розмірів селезінки, щзо визначається пальпацією та підтверджується ультрасонографією. Викладені основні тези щуодо впровадження класифікаціі спленомегалії у тварин з визначенням ізольованої та системної форм.

Ключові слова: селезінка, собаки, спленомегалія, ізольована, системна, ультрасонографія.

Постановка проблеми. В сучасній спеціальній літературі не існує єдиної точки зору щодо функції селезінки в життєдіяльності організму. Більшість науковців не вважають селезінку життєво важливим органом $[4,5,7,10]$. Проте це не означає, що йй належить другорядна роль. Селезінка виконує різноманітні функції в обміні речовин, відіграє велику роль у еритроцитопоезі, завдяки діяльності ретикулоендотелію і ендокринному впливу на обмін гемоглобіну, виявляє та здійснює підготовку до руйнування й утилізує патологічні формені елементи крові, регулює еритроцито-, лейкоцито- та тромбоцитопоез у кістковому мозку. Крім того, вона затримує бактерії та інші сторонні включення. Селезінка регулює об'єм циркулюючої крові за рахунок депонування, а також бере участь в обміні ліпідів [11].

Крім того, спеціальна капілярна сітка селезінки бере участь у регуляції портального кровообігу, тобто чисельні функції селезінка виконує за рахунок складної регуляційної системи, яка досі недостатньо вивчена.

За останні роки ідентифіковані нові патології селезінки, розроблені методи їх діагностики та лікування. Зокрема, найбільш поширеною реакцією селезінки на різні патологічні процеси в організмі є спленомегалія [3,9]. Це гостре чи хронічне збільшення селезінки, незалежно від етіологічного чинника. Проте публікації з приводу патології селезінки у тварин поодинокі i доволі розрізнені.

Отже, вивчення проблеми патологічних станів селезінки у тварин $\epsilon$ актуальним.

Аналіз основних досліджень і публікацій, у яких започатковано розв'язання проблеми. Аналізуючи публікації з приводу патології селезінки, слід зауважити, що у вітчизняних виданнях можна знайти лише поодинокі дослідження на цю тему. Загальні відомості щодо селезінки у тварин висвітлюють переважно топографію органу. В окремих роботах висвітлені особливості загальноклінічних методів дослідження селезінки. Так, у великої рогатої худоби її дослідити не вдається, у коней можлива лише часткова ректальна пальпація заднього іiі краю, у собак - бімануальна пальпація селезінки через черевну стінку. I лише за вираженої спленомегалії, яка може бути зумовлена гнійним запаленням, бактеріальними інфекціями або лейкозом, можливо виявити селезінку перкусією (велика рогата худоба та коні) або пальпацією (коні, собаки, коти). Одним 3 додаткових інструментальних методів дослідження селезінки є іiї пункція, на жаль, техніка якої описана лише у великої рогатої худоби та коней [6]. Загалом, більшість авторів вказують на значні труднощі у клінічній діагностиці патологічних станів селезінки, які часто виявляють лише патологоанатомічно $[5,6,10]$. Одним 3 інформативних i неінвазивних інструментальних методів досліджень селезінки у тварин є ультрасонографія, техніка якої описана переважно в іноземній [2] та окремих виданнях вітчизняної літератури [8].

Отже, аналіз літератури свідчить, що клінічне дослідження селезінки у тварин $\epsilon$ проблематичним, і можливе лише за спленомегалії. Також обмеженою $\epsilon$ інформація щодо збільшення розмірів і характеру ультрасонографічних змін селезінки за внутрішньої патології. 3 іншого боку, саме спленомегалія $\epsilon$ найбільш поширеною реакцією селезінки на різні внутрішні патології. Спленомегалія у тварин різних видів може бути 


\section{ВЕТЕРИНАРНА МЕДИЦИНА}

спричинена порушенням кровообігу, накопиченням пігменту білірубіну, гіпертрофією, гіперплазією, паразитарними захворюваннями, нагноєнням, кістозними ураженнями, пухлинами та іншими патологічними станами, на які селезінка реагує збільшенням свого об'єму [7]. У гуманній медицині існує низка класифікацій спленомегалії, переважно за етіопатогенетичними чинниками. Розрізняють спленомегалії ізольовані (солітарні) та спленомегалії системного типу. У ветеринарній медицині таку класифікацію не запроваджено. Отримані дані дали нам підставу спрямувати свої дослідження саме у цьому напрямі.

Мета досліджень - аналіз етіопатогенетичних чинників внутрішньої патології у собак, що супроводжується спленомегалією.

Основним завданням було вивчення проявів спленомегалії за різних патологічних станів організму.

Матеріали і методи дослідження. Дослідження проводили в умовах кафедри терапії Полтавської державної аграрної академії у період з 2009 по 2015 роки. Матеріалом для досліджень слугували клінічно здорові та хворі собаки, у яких відмічали збільшення селезінки. У ході виконання роботи використано результати досліджень 10-ти клінічно здорових та 73 хворих тварин. Основний діагноз, за необхідністю, підтверджували лабораторними дослідженнями біологічних субстратів та інструментальними методами.

Під час клінічного обстеження хворих тварин, у випадку встановлення діагнозу, звертали увагу на інформативність пальпації селезінки, а в разі отримання позитивного результату застосовували оглядову ультрасонографію органів черевної порожнини. Для порівняння досліджували клінічно здорових собак. Під час проведення ультрасонографії застосовували апарат SonoScape A6 vet (виробництво КНР) із трансдуктором 2-6 мГц.

Результати досліджень. У клінічно здорових собак селезінку знаходили у лівій частині черевної порожнини. У здорових тварин вона мала форму стрічки з гострими краями, які добре візуалізувались сонографічно.

Враховуючи точку зору М. Е. Комахідзе [7], до групи ізольованих спленомегалій ми відносили нозологічні форми, за яких патологічний процес розвивався переважно у селезінці без значних порушень інших функцій організму.

Це такі патології, як розриви органу, перекручування ніжки селезінки 3 гострим чи рецидивуючим перебігом, пухлини або кісти селезінки, ехінококоз селезінки, інфаркт, абсцеси, застійна селезінка, тромбоз вени селезінки та емболія се- лезінкової артерії. До спленомегалій системного типу ми відносили випадки, у яких, окрім збільшення селезінки, характерними були порушення функцій гемопоезу, що супроводжувалися анемією та жовтяницею (переважно гемолітичною), тобто лімфогранулематоз, лейшманіоз, патології, для яких характерні гемолітична анемія та гемолітична жовтяниця, тромбоцитопенії, цироз печінки тощо.

Спленомегалію у собак ми виявляли за окремих незаразних, інвазійних та інфекційних захворювань (див. табл.).

Як свідчать дані таблиці, у восьми собак (100\% випадків) спленомегалія розвивалась як ускладнення гострого розширення та завороту шлунку. У таких тварин селезінка була збільшена, неправильної форми, ніжка селезінки, утворена артерією та веною, була перекручена, що спричиняло порушення гемодинаміки.

Патофізіологічно це можна пояснити зміщенням селезінки каудовентрально під тиском дна розширеного шлунка, що призводить до розтягнення lig. gastrolienale та перекручування судин селезінки і спричиняє венозний застій у цьому органі. Оскільки селезінка є потужним депонуючим органом (може вміщувати до 16 \% об'єму крові [1]), розвивається спленомегалія i - селезінка займає більшу частину черевної порожнини.

Результати оперативного втручання зі спленектомією показали, що у таких випадках у селезінці розвиваються незворотні некротичні зміни. Дані випадки доцільно розглядати як ізольовану форму спленомегалії. Інвагінація кишечнику (сім тварин) супроводжувалася розвитком спленомегалії у $100 \%$ випадків.

Як відомо, дана патологія характеризується частковою або повною кишковою непрохідністю, що призводить до застою хімусу, розвитку бродильних і гнильних процесів, тобто кишкової аутоінтоксикації.

3 іншого боку, кишкова непрохідність спричиняє порушення кровообігу в органах черевної порожнини, водночас переважає венозний застій передусім у перипортальній ділянці.

У даному випадку спленомегалію слід віднести до групи системних і розглядати як компенсаторну реакцію селезінки, спрямовану на перерозподіл циркулюючої крові, а також спричиненою інтоксикацією організму.

Іншим захворюванням, що супроводжувалось спленомегалією у собак, був гепатит, що розвивався внаслідок різних етіологічних чинників (аліментарна інтоксикація, порушення обміну речовин, дія інфекційних агентів тощо). 
ВЕТЕРИНАРНА МЕДИЦИНА

Захворювання, що супроводжуються спленомегалією у собак

\begin{tabular}{|c|c|c|c|}
\hline \multirow{2}{*}{ Патології } & \multirow{2}{*}{ Усього хворих } & \multicolumn{2}{|c|}{ Спленомегалія } \\
\cline { 3 - 4 } & & 8 & голів \\
\hline Зміщення шлунку & 8 & 7 & 100 \\
\hline Інвагінація кишечнику & 7 & 10 & 100 \\
\hline Гепатит & 18 & 2 & 35,6 \\
\hline Цироз печінки & 6 & 3 & 100 \\
\hline Кісти селезінки & 3 & 3 & 75,0 \\
\hline Політравма & 4 & 26 & 100 \\
\hline Бабезіоз & 26 & 1 & 100 \\
\hline Ехінококоз селезінки & 1 & & \\
\hline
\end{tabular}

У 55,6 \% випадків селезінка була помірно збільшена, краї були притуплені, але не заокруглені. Розвиток спленомегалії за гепатиту має декілька причин. Це спільний портальний кровообіг печінки і селезінки, а також порушення пігментного обміну (білірубінемія) та анемія, що супроводжують розвиток гепатиту. Оскільки спленомегалія була виражена не у всіх тварин, хворих на гепатит, очевидно, іiі розвиток залежить від ступеню тяжкості патологічних процесів в організмі, тому її слід вважати системною. Досліджуючи собак, хворих на гостру та хронічну форми бабезіозу, ми встановили розвиток спленомегалії у $100 \%$ випадків. Збільшену селезінку виявляли пальпацією та підтверджували сонографічно. Лабораторними дослідженнями крові у таких собак встановлювали гемолітичні зміни крові, гіпохромну анемію та пойкілоцитоз, що дає змогу віднести таку спленомегалію до групи системних.

У трьох собак ультрасонографічно нами було виявлено поодинокі анехогенні утворення у паренхімі селезінки, розмірами 26, 34 та 58 мм. Водночас краї органу були заокруглені, а паренхіма набрякла. Проте клінічна картина крові у цих тварин не відрізнялась від показників здорових. Діагностичною лапаротомією виявлено неінвазивні кісти селезінки, заповнені прозорою рідиною, стінка яких утворена декількома шарами сполучної тканини та клітинами капсули селезінки. У однієї собаки виявили ехінококоз селезінки. Ці випадки можна класифікувати як ізольовану спленомегалію.

Спленомегалію виявляли також у собак, що надійшли до клініки після політравми внаслідок удару автомобілем (три випадки 3 чотирьох). Ультрасонографічно виявляли гіпоехогенні осередки у паренхімі селезінки різного розміру, неправильної форми. У двох собак контури капсули були нерівні. Лапаротомією встановили розриви селезінки 3 масовими крововиливами під капсу- лу, а у двох тварин - у черевну порожнину. Лабораторний аналіз крові показав нормохромну анемію, гіповолемію, зниження ШОЕ, тобто зміни, характерні для постгеморагічного стану. Це випадки ізольованої спленомегалії.

Спленомегалію за цирозу печінки спостерігали у двох 3 шести тварин. Водночас у трьох тварин були присутні ознаки асциту. Спільними лабораторними показниками були білірубінемія з рисами паренхіматозної жовтяниці, гіперхромна анемія, тромбоцитопенія, висока активність «печінкових» трансаміназ, лужної фосфатази та показників стану сполучної тканини. Такі випадки доцільно віднести до системних спленомегалій.

Отже, результати досліджень свідчать, що спленомегалія супроводжує перебіг цілої низки патологій різної етіології та патогенезу. У одних випадках збільшення селезінки $є$ наслідком, у інших - важливою патогенетичною ланкою. Враховуючи вищевказане, класифікація спленомегалій різної етіології у тварин дає можливість клініцисту своєчасно зорієнтуватися у складних патофізіологічних процесах, що відбуваються у хворому організмі.

Висновок. Селезінка $\epsilon$ важливим кровотворним, імунним та депонуючим органом, роль і фізіологічне значення якого до кінця не вивчені наукою.

Інформативність клінічного дослідження стану і функцій селезінки обмежена, що вимагає пошуку нових інформативних методик досліджень цього органу.

Спленомегалія є одним із проявів реакції селезінки на патофізіологічні зміни у організмі тварин, вивчення якої заслуговує на увагу та вимагає значного об'єму досліджень.

Складність причинно-наслідкових зв'язків селезінки 3 патологіями інших органів і систем організму вимагає пошуку раціональної класифікації спленомегалії у ветеринарній медицині. 


\section{БІБЛІОГРАФІЯ}

1. Анатомия домашних животных / [Акаевский А. И., Юдичев Ю. Ф., Михайлов Н. В., Хрусталева И. В.] ; под ред. А. И. Акаевского. - [4-е изд., испр. и доп.]. - М. : Колос, 1984. - С. 399-401.

2. Барр Ф. Ультразвуковая диагностика собак и кошек / Ф. Барр. - М. : Аквариум-ЛТД, 1999. $250 \mathrm{c}$.

3. Барта И. Селезенка (анатомия, физиология, патология и клиника) / И. Барта [пер. с нем. М. Сиза]. - Будапешт, 1976. - 264 с.

4. Ботвинков Н. И. Диагностика и лечение заболеваний и травм селезенки / Н. И. Ботвинков, П. В. Горелик // Вестник хирургии им. И. И. Грекова. - 1989. - №10. - С. 131-133.

5. Гольиман K. M. Краткий курс частной патологии и терапии домашних животных / К. М. Гольцман. - М., 1930. - С. 330.

6. Клінічна діагностика внутрішніх хвороб тварин / [Левченко В. І., Влізло В. В., Кондрахін І. П. та ін.] ; за ред. В. І. Левченка. - Біла Церква, 2004. - C. 450.

7. Комахидзе М. Э. Селезенка / М. Э. Комахидзе. -
М. : Наука, 1971. -255 с.

8. Локес П. І. Ультразвукова діагностика хвороб дрібних тварин / П. І. Локес, В. Г. Стовба, Л. П. Каришева. - Полтава : ФОП Говоров С. В., 2007. - $128 \mathrm{c}$.

9. Хирургические болезни : учебник / [Кузин М. И., Шкроб О. С., Кузин Н. М. и др.] ; под ред. М. И. Кузина. - [3-е изд., перераб и доп.]. - М. : Медицина, 2002. - С. 388-400.

10. Частная патология и терапия домашних животных / [Гутира Ф., Марек И., Маннингер Р., Мочи И.]. - М. : Изд-во с/х литературы, журналов и плакатов, 1963. - Т. II. - С. 51-53.

11. Seifert M. F. The regulation of hemopoiesis in the spleen / M. F. Seifert, S. C. Marks // Experientia. 1985. - V. 41. - №2. - P. 192-199.

12. Splenic size and duplex sonography determination of blood flow in the vena lienalis and vena portae in liver cirrhosis / [Haag K., Weimann A., Zeller O. et al.] // Bildgebung. - 1992. - V. 59. P. 80-83. 